\title{
EVIDENCE BASED LEARNING: AN ANALYSIS OF IMPACT ON RETENTION OF KNOWLEDGE
}

\author{
Prashant Thote ${ }^{*} \bowtie$, Gowri. S 2 \\ ${ }^{* 1}$ Gyanodaya Vidya Mandir, India \\ ${ }^{2}$ Gyanodaya Vidya Mandir, India
}

DOI: https://doi.org/10.29121/granthaalayah.v8.i10.2020.1883

Article Type: Research Article

Article Citation: Prashant Thote, and Gowri. S. (2020). EVIDENCE

BASED LEARNING: AN ANALYSIS

OF IMPACT ON RETENTION OF

KNOWLEDGE. International Journal

of Research -GRANTHAALAYAH,

8(10), 224-235.

https://doi.org/10.29121/granthaa

layah.v8.i10.2020.1883

Received Date: 02 October 2020

Accepted Date: 31 October 2020

Keywords:

Chemistry

Learning

Conventional Methodology

Learning Outcomes and Innovations

\begin{abstract}
Chemistry is a fundamental discipline of Science that accounts for day to day life at molecular level. The major challenge in the classroom instructions is to bridge the gap between high demand of learning and low efforts of learners due to lack of motivation. In this paper attempt is made to correlate the subject with day to day life. The objectives of the classroom instructions are to make effective and efficient delivery of instruction, knowledge, skill, attitude and competence. The aim of the present study is to make Chemistry subject vivid, joyful understanding of concept to stimulate learners intellectual curiosity to enhance the learning. In this study total 50 students participate. The students are categorized into two groups (study group and the control group). Each group consists of 25 students. Quasi experiment research design is applied. Data is collected by using question paper based on Revised Bloom's Taxonomy (RBT) before and after the experiment. Result of the study reveals that the evidencebased learning approach is used for the classroom instructions and has positive impact on motivation, satisfaction and academic achievement. The present classroom instruction is beneficial because it correlates the subject with day today life and arouses the interest among the learners. Based on the findings of the study some suggestions are made.
\end{abstract}

\section{INTRODUCTION}

"Education without application is just entertainment" - Tim Sanders

Learning climate influences learners' achievement. Teaching -learning approach where learners are engaged with performing tasks are more advocating. The students interact with their ambience for accumulating information, retrieve and use their knowledge, skill and competence in such a way that it is useful for the society at large. The students face challenges in learning Chemistry due to its abstract nature of concept, need for noteworthy time, committed efforts from learners and teachers also. The contrast between the low input and high demands results in not satisfying performance from learner's side and frustration on teacher's side.

According to modern research, there are large numbers of learners who find it difficult to assimilate concepts during classroom instruction. The low academic performance may be due to poor classroom instructions, ineffective teaching methodology, fragmented content knowledge and students with limited mental ability, not sufficient understanding and learners' common sense. The classroom instructions can improve students' learning by inspiring student's curiosity in the subject.

(C) 2020 The Author(s). This is an open access article distributed under the terms of the Creative Commons Attribution License, which permits unrestricted use, distribution, and reproduction in any medium, provided the original author and source are credited. 
In the present study the approach used for classroom instructions is to correlate the Chemistry subject with day to day life. Chemistry touches all spheres of life. As a teacher for the past 25 years I am able to connect the depth of Chemistry with everyday life. One may find Chemistry in day to day life like in the air we breathe, food we eat, cleaning chemicals we use and literally in every object we touch and even in our emotions.

All main branches of Science - Biology, Chemistry and Physics are useful to the humanity in one way or other. But leading out of these is Chemistry. There is hardly any aspect of our life where Chemistry does not have impacted. The multicolor cloths we wear utilize different dyes, the cosmetics, creams, shampoos and detergents involve the skills of Chemistry. The most vital of these are various medicines and drugs which are organic compound. We must be grateful to the chemists who carry out these researches in different parts of the world to synthesis new medicines.

Chemistry teacher employs different teaching methodology in classroom instructions, some work with the students but others may not. The important issue that arises in Science classroom instruction is presenting information through chalk and talk- the passive learning. Learners who receive this type of instructions remain inactive during the classroom instruction and are of the opinion that Chemistry knowledge is fixed and no additional action is required. Students who are passive in the classroom instructions are likely to be the low achiever.

To felicitate learning in core subjects including Chemistry many efforts have been initiated into the wide spectrum of activities that aims to help teachers shift from teacher center pedagogy to learners centered pedagogy including many leaning activities to amalgamate in the classroom instructions.

Active learning process provide multiple opportunities and enough time for learner's interactions by engaging them to construct positive understanding of concepts, gain knowledge, acquire skills and apply their competency. Active learning includes conceptual understanding, changing strategies, collaborative learning, co-operative learning, group work, technology enhanced inquiry based, problem based, case study based discovery learning, peer instructions and experiential learning activity. Different engaging teaching techniques have been used in Chemistry classroom. The conceptual visualization has an optimistic effect on Chemistry learning outcomes and concept mapping is effective and efficient in gaining knowledge, acquiring concept and to apply competency. The concept mapping is more effective in enhancing academic achievement than conventional teaching methodology. The highly directed concept mapping techniques produce much better result in learner's academic performance then poor concept mapping.

Students construct Chemical concepts at their own paces based on their daily experiences. Therefore, learners' are provided with an opportunity and enough time to develop sound understanding of Chemical concepts during class-room instructions. The best teaching practice is to give students a particular task at both individual and group level at with a given time frame work. Self-determined time produces better academic achievement result at practical Chemistry than the other teaching methodologies such as lectures demonstration etc. The most commonly used teaching methodologies are role play, project, quiz, oral questions, field visit, debate, problem solving, individual work, investigation assignments, practical work, test, presentation and discussion.

Table 1: Selected everyday life correlated Chemical Concepts

\begin{tabular}{|c|c|c|c|}
\hline $\begin{array}{c}\text { Sl } \\
\text {.No }\end{array}$ & Concepts & Everyday life Connection & Pictures \\
\hline 1 & Density & HDL and LDL - good and bad cholesterol & Cholesterol - Areries \\
\hline 2. & Second law of thermodynamics & Why is it easy to stay messy while hard to \\
& & keep neat & \\
\hline
\end{tabular}


Evidence Based Learning: An Analysis of Impact on Retention of Knowledge

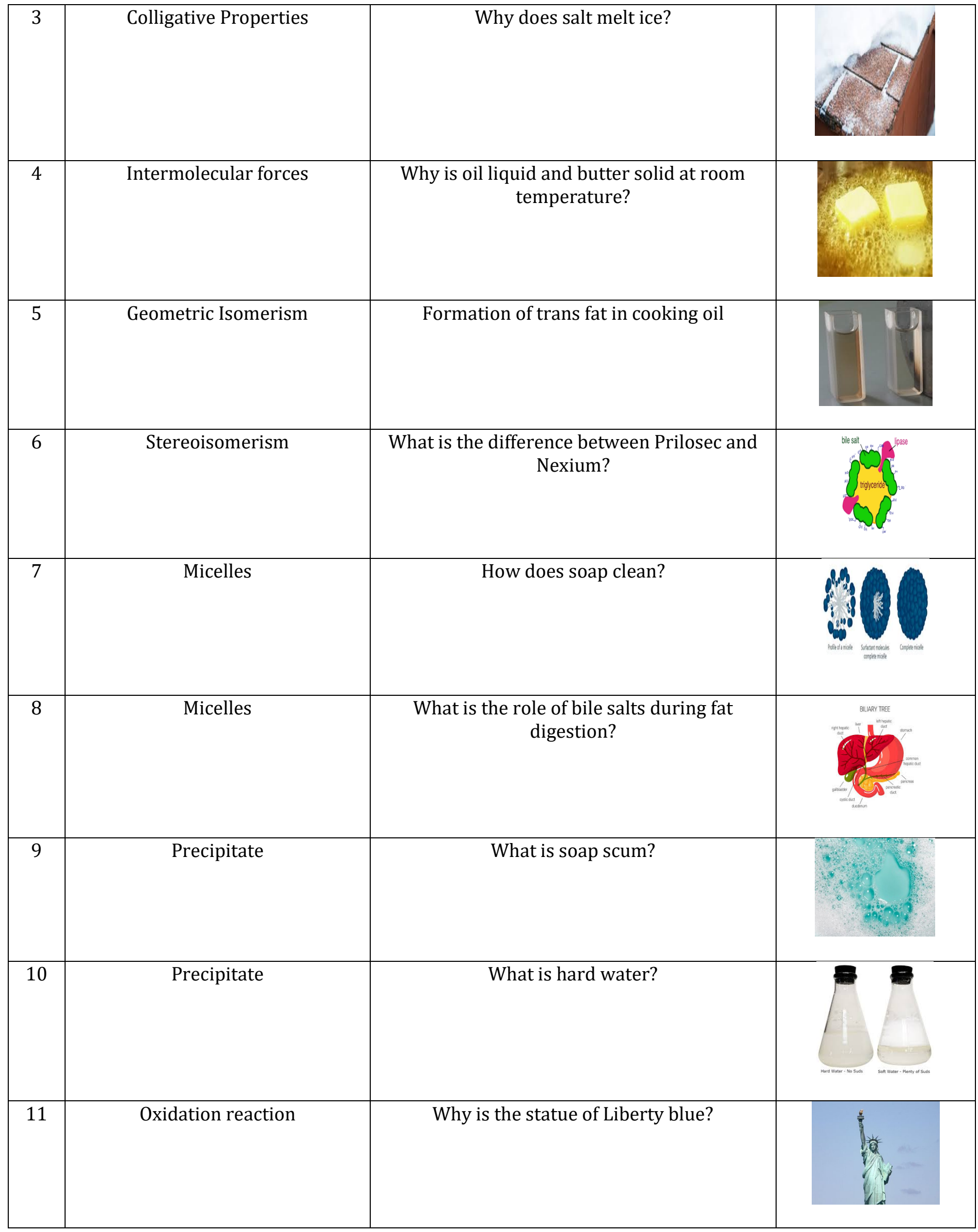


Prashant Thote, and Gowri. S

\begin{tabular}{|c|c|c|c|}
\hline 12 & Oxidation reaction & How does rust work? & \\
\hline 13 & Catalytic hydrogenation & Manufacturing of Margarine & \\
\hline 14 & Base catalyzed hydrolysis & How is soap made? & \\
\hline 15 & Acid catalyzed hydrolysis & $\begin{array}{c}\text { How do drug-sniffing dogs detect illegal } \\
\text { drugs? }\end{array}$ & \\
\hline 16 & Nucleophilic addition-elimination & How does penicillin work? & 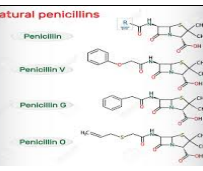 \\
\hline 17 & Nucleophilic addition-elimination & How is aspirin made? & \\
\hline 18 & Nucleophilic addition-elimination & How is nylon 6-6 made? & \\
\hline 19 & Chromic acid oxidation & How do breathalyzers work? & \\
\hline 20 & Polymerization of alkenes & How is plastic made? & \\
\hline 21 & Polymerization of alkenes & How is PCV made? & \\
\hline
\end{tabular}


Evidence Based Learning: An Analysis of Impact on Retention of Knowledge

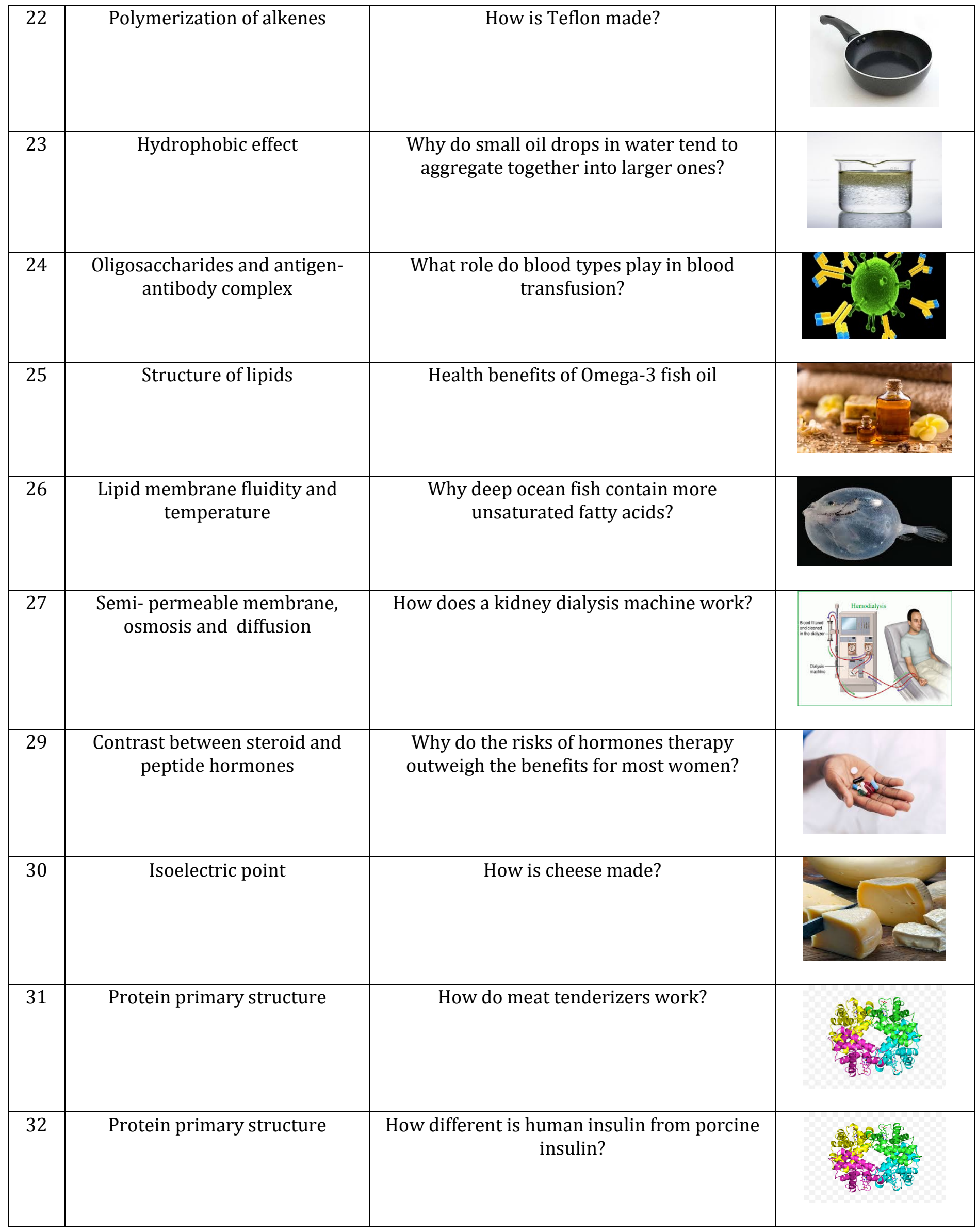


Prashant Thote, and Gowri. S

\begin{tabular}{|c|c|c|c|}
\hline 33 & $\begin{array}{l}\text { Protein tertiary structure- } \\
\text { disulfide bond }\end{array}$ & What is involved in a "hair permanent"? & $\begin{array}{l}323 \\
35-3 \\
\text { mmon }\end{array}$ \\
\hline 34 & Fibrous and globular proteins & $\begin{array}{l}\text { Why is hair water insoluble while egg white } \\
\text { soluble? }\end{array}$ & 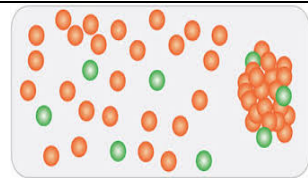 \\
\hline 35 & Protein Denaturation & $\begin{array}{l}\text { Why is raw egg white water soluble while } \\
\text { cooked egg white insoluble? }\end{array}$ & \\
\hline 36 & Protein Denaturation & Why does alcohol sterilize things? & \\
\hline 37 & Protein Denaturation & Why must we wear goggles in the lab? & \\
\hline 38 & Hemoglobin and Iron & $\begin{array}{l}\text { Why is venous blood dark red while arterial } \\
\text { blood bright red? }\end{array}$ & \\
\hline 39 & Myoglobin & Why is beef red while fish white? & \\
\hline 40 & Glycoproteins & $\begin{array}{l}\text { Why do we need to do "Type and cross } \\
\text { match" test before a blood transfusion? }\end{array}$ & \\
\hline 41 & Antigens and antibodies & $\begin{array}{l}\text { Why do we need to do "Type and cross } \\
\text { match" test before a blood transfusion? }\end{array}$ & 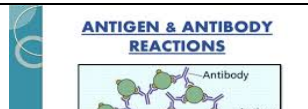 \\
\hline 42 & Enzyme specificity & $\begin{array}{l}\text { How is it possible that humans cannot digest } \\
\text { grass while cows can? }\end{array}$ & 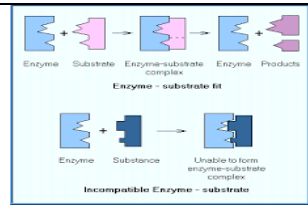 \\
\hline
\end{tabular}


Evidence Based Learning: An Analysis of Impact on Retention of Knowledge

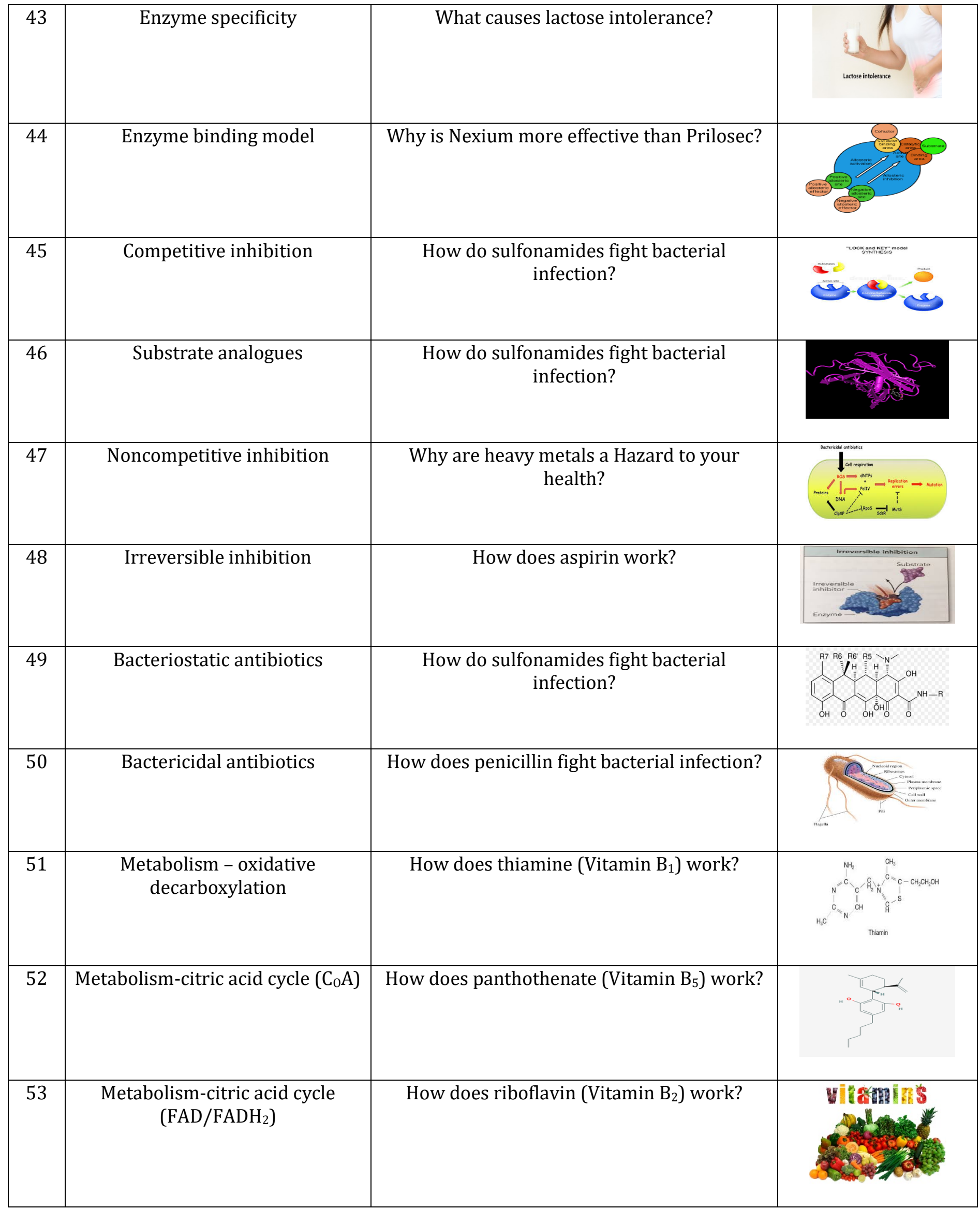


Prashant Thote, and Gowri. S

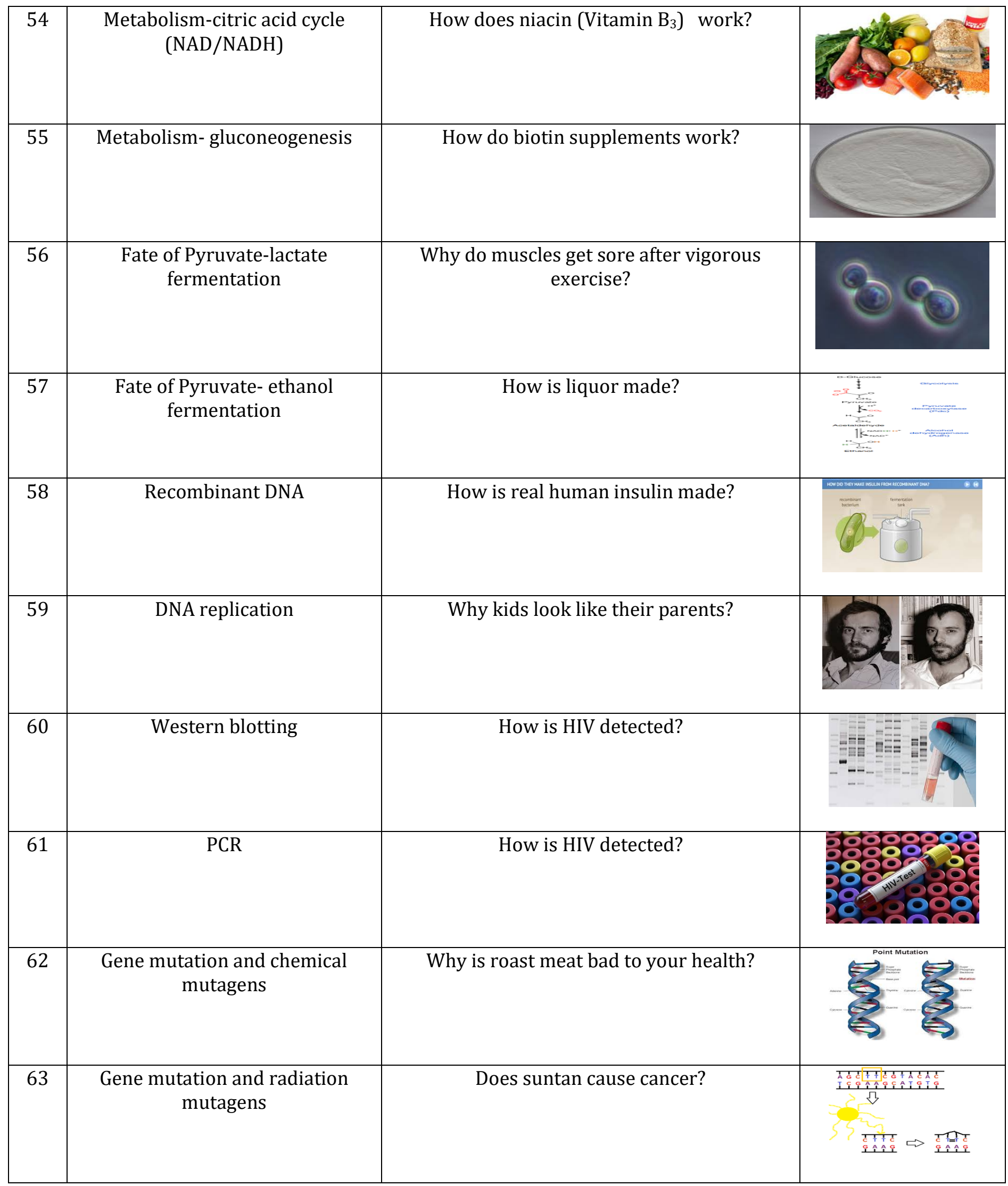


Evidence Based Learning: An Analysis of Impact on Retention of Knowledge

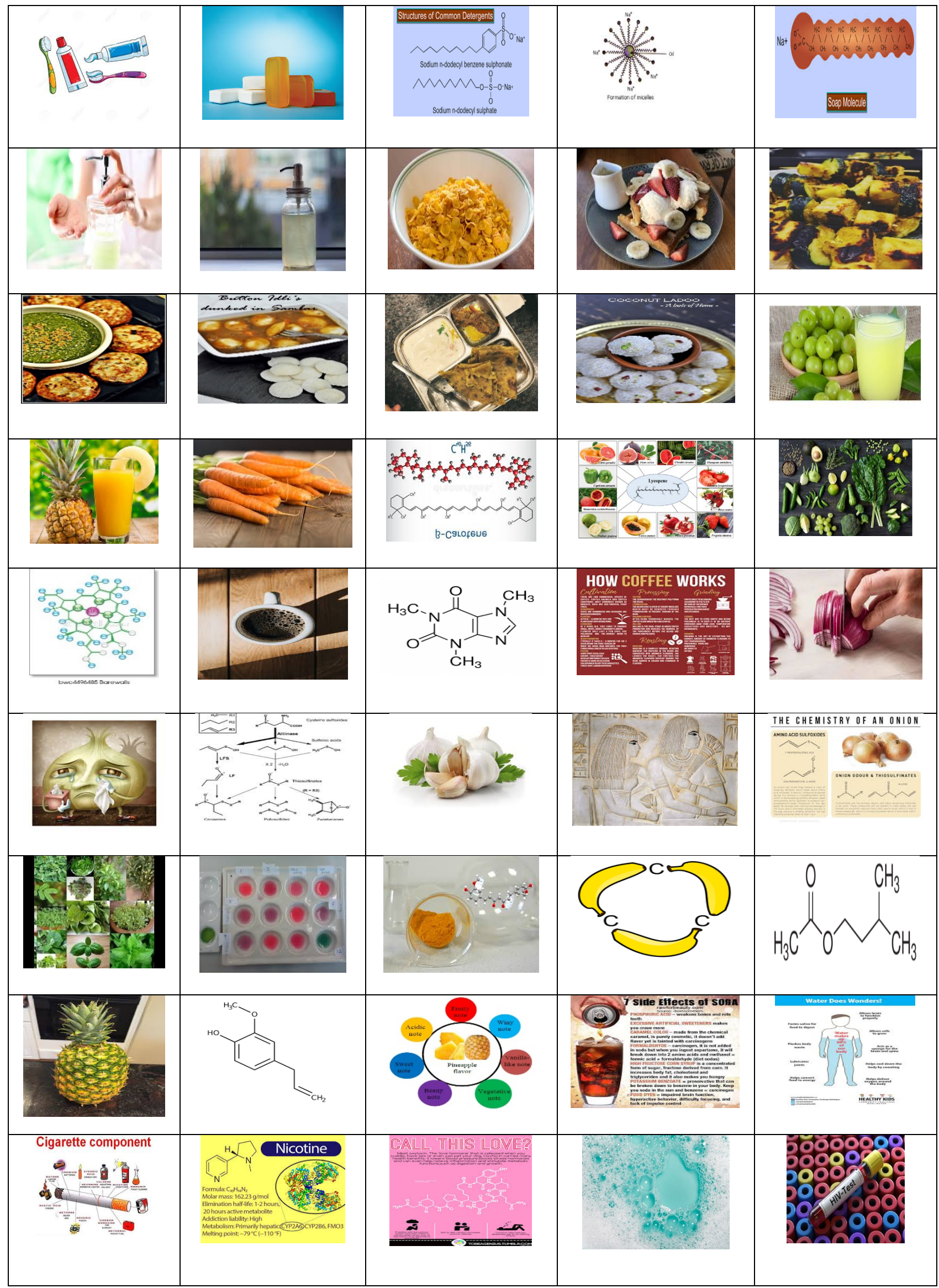

Figure 1: Chemistry in Everyday Life 


\section{METHODS}

\subsection{SIGNIFICANCE OF THE STUDY}

The introduction of alignment of concept of Chemistry to everyday life is improving learning and the academic achievements of the students. This will foster more joyful learning experience and arose the interest in the subject by intrinsic motivation.

The imperial evidences to support the present classroom strategies in Chemistry at intermediate level is not known, without knowing the imperial evidence it is unlikely to convince teachers to use the present classroom instruction method for teaching and learning Chemistry and other core subject of school education at intermediate level.

\subsection{OBJECTIVES}

The present study aims to study the outcome of present teaching learning strategies on academic achievement score of study group and control group.

\subsection{HYPOTHESIS}

There is no noteworthy mean score difference between the academic achievement score of study group and control group after treatment.

\subsection{RESEARCH DESIGN}

Fig 2.

The (quasi) experimental research design is applied. The systematic description of design is represented in

\subsection{SAMPLE}

The sample consists of total 50 students of grade 12 studying Chemistry as elective subject. Sample age is from 17-19 years. On the basis of the test conducted before the treatment, the samples are subdivided into two groups (study and control group) - 25 students in each. Both group consists of 25 students.

\subsection{TOOL}

As there is no standard tool available to measure the academic achievement after treatment, test is designed. According to RBT (Revised Bloom's Taxonomy) the content of the instrument is validated by the subject experts.

\section{RESULT AND DISCUSSIONS}

Table 1: Independent sample t-test before treatment of student's achievement:

\begin{tabular}{|c|c|c|c|c|c|}
\hline Variables & N & Mean & df & t-value & P \\
\hline Study Group & 25 & 14.23 & 58 & 0.177 & 849 \\
\cline { 1 - 3 } Control Group & 25 & 14.02 & & & \\
\hline
\end{tabular}

Table 2: Independent sample t-test after treatment of student's achievement:

\begin{tabular}{|c|c|c|c|c|c|}
\hline Variables & N & Mean & df & t-value & P \\
\hline Study Group & 25 & 18.52 & 58 & 12.68 & .000 \\
\cline { 1 - 4 } Control Group & 25 & 16.29 & & & \\
\hline
\end{tabular}


Evidence Based Learning: An Analysis of Impact on Retention of Knowledge

Table 3: Paired Sample test for test before and after treatment

\begin{tabular}{|c|c|c|c|c|c|}
\hline Pair 1 & Before and after treatment of test & Mean difference & SD & $\mathrm{T}$ & $\begin{array}{c}\text { Significance } \\
(2 \text { trailer })\end{array}$ \\
\hline & & -4.2000 & 1.45 & 12.442 & .000 \\
\hline
\end{tabular}

The independent t-test sample is applied to calculate the mean score difference between he achievement score of study group and the control group on test before treatment.

Table 1 shows that there is no noteworthy difference between two groups ( $\mathrm{p}=849)$. It shows that both groups are on equal level of achievement before interventions.

A paired t-test sample is conducted to compare the effect of treatment on academic performance of the study group. Table 2 reveals that there is a noteworthy difference in the academic performance of test before the treatment $(\mathrm{M}=18.52, \mathrm{SD}=4.261)$ and after treatment $(\mathrm{M}=16.29, \mathrm{SD}=3.460) \mathrm{t}(50)=12.442, \mathrm{p}=0.000)$.

\section{DISCUSSION}

The present study is conducted to reveal the effect of correlation of Chemistry with everyday life to gain sound results. Learners are subdivided into two groups (study group and control group). Study group is taught the subject on the center of correlation of the subject with day to day life and control group is taught by using conventional method. Result of the study indicates that the present study indicates that the present strategy of class room instructions have positive impact on students' academic performance. Result of the present study is in constant with previous study Chunuu and J. Foss (2010).

The present classroom strategy proves to promote learning. Learners in the classroom express their satisfaction with the teaching methodology. Students express their satisfaction as students succeed in Chemistry subject with high grades not only making subject easy but also stay in tune with students. The classroom instructions are understandable to more difficult content like electrochemistry, chemical equilibrium and solid states.

In order to compare the students score with knowledge and competency, the mediocre score of the students are taken and the result reveals that the student's average scores have increased by $18 \%$ and exceeded the intended benchmark. The merit of incorporating answers into classroom instructions is advisable that analogy may also cause confusion by itself in two aspects:

- Students are not familiar with analogy of class room instructions

- Students have different understanding of point of instruction which they wish to convey. Hence having proper metaphors and repetitive specifying the differences and similarities between the concepts and analogy is essential.

\section{CONCLUSION}

- Innovative class-room instructions practices improve both learners and teachers. By involving in innovative practices, students need not be categorized. Students prefer learning by doing (experiential learning).

- Innovative classroom instructions are promising because it supports teachers to involve students with learning.

- Innovative practices are prominence in Science education, curriculum, teaching-learning and value additions.

- Present emphasis is on adopting subject knowledge and skills to everyday life. Hence Science teachers must concentrate on this to connect the subject with daily life to have firsthand knowledge of the subject.

- When teachers and learners fully embrace innovative process in classroom, students' academic achievement enhances greatly in Science subject.

\section{SUGGESTION FOR IMPROVEMENT}

- Teachers should design, fabricate, innovate various teaching methodology for class room instructions to enhance students active participation in lesson to enhance academic performance. 
- In service teacher training should be organized for continuous improvement in class-room instructions and overall quality of education.

- Teachers should visit other schools that utilize innovative classroom practices, observe new methods and material in action.

- Science teachers should be motivated to become more cosmopolitan in applying classroom teaching techniques.

\section{SOURCES OF FUNDING}

This research received no specific grant from any funding agency in the public, commercial, or not-for-profit sectors.

\section{CONFLICT OF INTEREST}

The author have declared that no competing interests exist.

\section{ACKNOWLEDGMENT}

None.

\section{REFERENCES}

[1] Ajunwa, C. (2000), Acquisition of physics process skills by secondary school students, Department of Education, University of Nigeria, Nsukka.

[2] Amanso, E. O.I., \& Bassey, B.A. (2017), Assessment of Selected Science Process Skills Acquisition among Senior Secondary Schools Students in Calabar Education Zone of Cross River State, Nigeria. International Journal of Scientific Research in Education, 10(1), 119-126

[3] Ayas, A., Cepni, S., Akdeniz, A., Ozmen, H., Yigit, N., \& Ayvaci, H.S. (2007), Science and Technology Teaching from Theory to Application (6th Ed.). Ankara; Pegem A Publishing.

[4] Terniz, B.K., Assessing Science Process Skills in Physics Teaching (Ph.D. Thesis). Gazi University, Institute of Education Science, Ankara, Turkey.

[5] Prashant Thote, Experiential Learning: Inclusive Art Education for Joyful Learning, Review of Research, Vol 8, Issue- 09, June 2019.

[6] Prashant Thote, Experiential Learning: Model for Teaching Science at Grade Nine, Research Magma, Vol-3, Issue -06, August - 2019. 